MARYNA ADAMSKA ${ }^{1}$

${ }^{1}$ Department of Geomorphology, Institute of Geography and Regional Development, University of Wrocław, Uniwersytecki sq. 1, 50-137 Wrocław. E-mail: maryna.adamska@uni.wroc.pl

\section{Riparian buffer zones on selected rivers in Lower Silesia - an important conservation practice and the management strategy in urban planning}

\section{KEY WORDS:}

riparian buffer zones, buffer strips, rivers, vegetation cover, agricultural

\section{ABSTRACT}

Buffer zones are narrow strips of land lying along the surface water, covered with appropriately selected vegetation. They separate aquatic ecosystems from the direct impact of agricultural land and reduce the movement of nutrients in the environment. In 2008 the European Commission established requirements for the implementation of buffer strips along water courses. Poland committed to the enforcement of these requirements until 1 January 2012. This was one of the reasons of this study. The subject of the analysis included the following rivers in Lower Silesia: Smortawa, Krynka, Czarna Woda and the selected transects of Ślęza and Nysa Łużycka. Detailed studies were designed to estimate the buffer zones occurring on these watercourses and assess these zones' structure. This will be used to develop clear criteria for the selection of the width of these zones based on land use land management. It can be used in the implementation of executive acts at different levels of space management. Field research consisted of inventory the extent of riparian buffer strips on selected water courses and photographic documentation. Species composition of the vegetation forming a buffer zone was identified by using Braun-Blanquet method. There was lack of continuity of the riparian buffer zones on investigated rivers. Buffer zones should have carefully formulated definition and width because they are element of the significant ecological value, they perform important environmental protective functions and they are also the subject of Community law. 
Introduction

Water is a limited resource, so water quality is recently one of the major issues of an international concern. (Fielding et al. 2005). Intensive agriculture and urban development can have a negative impact on stream ecosystems. Riparian buffer zones are highly recommended to reduce the impact of urbanization and farming on the aquatic ecosystems and improve the water quality (Agouridis \& Wighman 2010). Riparian buffer zones are ecological boundaries or ecotones separating terrestrial and aquatic ecosystems. They are important elements, that control sediment and nutrients movement through the catchment system. Because of their ecological significance they has become a tool in proper land use management practices (Burt et al. 2002). These areas between land and a surface water body consists of specific type of vegetation. They act as a barriers and play role in many biological, chemical and physical processes. Riparian buffers protect the water from land use practices (Blackwell et al. 1999).

Riparian areas perform multiple ecological functions. They regulate sediment removal, control erosion, moderate the shade and water temperature, maintain the habitat structural diversity and improve the landscape quality (Broadmeadow \& Nisbet 2004). They have been also admitted to be landscape components that promote faunal movement and enhance gene flow (Fisher et al. 200o). The influence of the riparian buffer depends on its width, structure, plants composition and the management of this area (Broadmeadow \& Nisbet 2004).

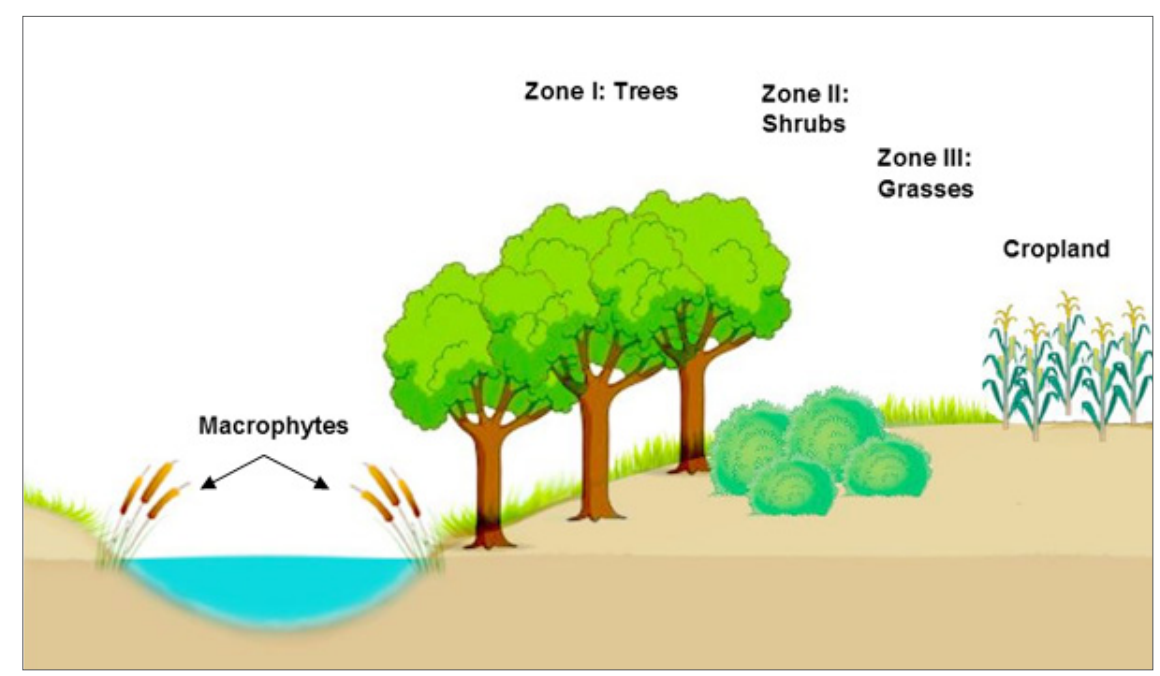

Main criteria to identify appropriate buffer width include: resource functional value, intensity of adjacent land use, buffer characteristics and specific buffer functions required. Many agencies rely primarily on a mixture of political acceptability and resource functional value to determine buffer standards (Castelle et al. 1994). The most of the buffer design studies is concerning on the required width, but the vegetation assemblage, layout, slope of adjacent lands, and length are also key design parameters. Major buffer strip width recommendations for improving or protecting water quality tend to be between 10 and $30 \mathrm{~m}$ (Fischer et al. 2000).

Vegetation used for buffer designs should constitute a mix of trees, shrubs, and herbaceous plants that are native to the region and well-adapted to the climactic, soil, and hydrologic conditions of the site (Fischer \& Fischenisch 2000)

There are few possibilities in designing riparian buffer system. One recommended concept consists of 3 zones. The first zone is unmanaged forest of fast- and slow-growing water-tolerant trees along the stream bank, the second zone consists of the shrubs and is located next to the trees. The third zone is occupied by grasses. The perfect solution is when zones are left undisturbed; however Zone 3 can be mowed or grazed once fully established (Agouridis \& Wightman 2010). Within each of these plant communities, a wide variety of species and zone widths can be used depending on design requirements (Schultz et al. 2004). This kind of riparian buffer system is shown on the figure 1 .
Fig 1. Riparian buffer system with three zones (based on Schultz et al. 2005, modified). 
Another design model includes 2 zones the first zone is unmanaged forest adjacent to water (left unmanaged to provide shading and large woody debris to the stream). The second zone consists of managed forest with systematic harvests to remove trees. The third zone consists of a herbaceous filter strip that intercepts and slows the usually concentrated surface runoff from adjacent fields and spreads it over a wider front to move more slowly through the riparian buffer (Schultz et al. 2004).

Sometimes landowners refuse having zone with unmanaged forests because of the trees falling into streams and slowing water. As the result the other design project has been developed - two-zone multi-species riparian buffer consisting primarily of a woody zone and a grass or grass-forb filter zone. The whole woody zone is managed but may be planted to combinations of trees and shrubs (Schultz et al. 2004). Buffers can also consist entirely of grass (grass filter strips), but fewer benefits are provided by that approach. (Agouridis \& Wightman 2010).

In many countries, after recognizing the importance of riparian buffers riparian restoration and preservation programs have been established. Poland, as a member of the European Union, committed to the adoption of Community law. In European law there is a requirement to implement the riparian buffers. Poland should have included it by the 1.01.2012. There should have been made changes in Polish law and land use management documents. In 19.01.2009 in the regulation: RozPorząDZENIE RADY (WE) NR 73/2009 requirement concerning on implementation riparian buffers was established. In Environmental Management Scheme based on RoZPORZĄDZENIE RADY (WE) NR 1257/1999 (about support for rural development) and ROZPORZĄDZENIE KOMISJI EUROPEJSKIEJ 445/2002 9 packets were designed. Packet $\mathrm{nr} 9$ is about creating riparian buffer zones. Although in Polish law there have been some minor changes, they can only be named 'mentions'. No strict definition of riparian buffer zones have been reported. There are no conditions referring to an extent, width and composition of riparian buffer zones. However landowners can receive money support ranging from $40 \mathrm{z} / / 100$ linear meter. to $110 \mathrm{zł} / 10 \mathrm{O}$ linear meter. This amount depends on the width of this zone that farmer would constitute and the class of the soil. Of course there is no authority which could carefully checked if there are no frauds in implementing buffer zones. Another matter that is worth mention is the fact, that landowner can choose only one from nine packets and still obtain a financial compensation (even if according to the law buffer strips are obligatory).
Study area

All rivers selected for further analysis are located within territory of Lower Silesia. The investigation was carried out on five rivers: Krynka, Czarna Woda, Smortawa and selected transects of Ślęza and Nysa Łużycka. The location of the investigated rivers is shown on the figure 2.

According to regionalization by Kondracki (2002) the discussed rivers flows in the territory of Lower Silesia, the area located within two provinces: North European Plain and Bohemian Massif.

The investigated transect of Ślęza river (from $\mathrm{km} 14+700$ to $\mathrm{km} 39+300$ ) is situated within makroregion Silesian Lowlands (mezoregion Wrocławska Plain and Wrocławska Proglacial Valley) and Sudeten Foreland (mezoregion Niemcza-Strzelin Hills) (Kondracki 2002). Ślęza is a left-hand tributary of Odra river. It has length of $78,6 \mathrm{~km}$ and the catchment area is $971,7 \mathrm{~km} 2$. It has two maximums of discharge in March and April (Staśko 2005). This is typical for lowlands rivers. The source of the river is situated in the Niemcza-Strzelin Hills in the vicinity of the Bobolice at an altitude of 340 $\mathrm{m}$ above sea level. The mouth of the river is below the disctrict of Kozanów in Wrocław city in $261,6 \mathrm{~km}$ of the Odra river.

Czarna Woda flows in area of the makroregion Sudeten Foreland (mezoregion Ślęża Massif) and makroregion Silesian Lowlands (mezoregion Wrocławska Plain) (Kondracki 2002). It is the right-hand tributary of 


\begin{tabular}{|l|l|l|l|}
\hline CONTEMPORARY TRENDS IN GEOSCIENCE & VOL. 2 & MARYNA ADAMSKA \\
\hline & $\begin{array}{l}\text { Riparian buffer zones on selected rivers in Lower Silesia - an important conservation } \\
\text { practice and the management strategy in urban planning }\end{array}$ \\
\cline { 2 - 3 }
\end{tabular}

Bystrzyca river. The source of Czarna Woda is located in the slopes of the Radunia mountain at an altitude of $325 \mathrm{~m}$ above sea level. The mouth of the river is nearby the area of Kąty Wrocławskie. This river is the main watercourse in Ślęża Landscape Park. It has maximum flow occurring in spring and summer. Because in many places river flows within village area and there is no riparian vegetion there, when the rainfall increases, the water level rises and, as the result, the village can be flooded. In 2009 multiday rainfall caused the rising of the water in Bystrzyca and also the water of Czarna Woda has risen up. 130 houses in communes Marcinowice and Sobótka were flooded. The biggest damages were recorded in the village Strzelce Świdnickie (Kasprzak 2010).

Krynka belongs to the area of the makroregions Sudeten Foreland (mezoregion Niemcza-Strzelin Hills) and Silesian Lowlands (mezoregion Wrocławska Plain) (Kondracki 2002). Krynka is third-order stream, the right-hand tributary of Oława. The source of this small (about $36 \mathrm{~km}$ ) river is located at altitude of $310 \mathrm{~m}$ above sea level in Goworowice village in Opole Province and the mouth of the river is in Lower Silesia below Strzelin at $185 \mathrm{~m}$ above sea level. The river valley is flat-floored and gets wider with the water course reaching a maximum of 1,5 $\mathrm{km}$ width. Maximum water flow is in spring and summer. Average annual discharge is 0.5 m3/s (Parzóch \& Solarska 2008). The catchment has agricultural character. Because of the possibility of flood in 2006 the reservoir in Przeworno was built (Malczewska et al. 2011). Smortawa is located within makroregion Silesian Lowlands (mezoregion Wrocławska Proglacial Valley and Olesnicka Plain). Smortawa is typical lowland river with two maximum water flow in spring and summer. It is the right-hand tributary of Odra and it has a length of $39 \mathrm{~km}$. The source of the river is located at altitude of $175 \mathrm{~m}$ above sea level in south-east from Namysłów in Opole Province and the mouth of the river is in Lower Silesia above Wrocław near Jelcz at $124 \mathrm{~m}$ above sea level. The average size of annual rainfall in the catchment is $577 \mathrm{~mm}$. The river flows mainly among forests and meadows. There are many nature reserves nearby (Adynkiewicz-Piragas et al. 2006).

The studied transect of Nysa Łużycka (km $154+600$ to $\mathrm{km} 82+400$ ) is located within 3 makroregions: Foothills Zachodniosudeckie (mezoregion Żytawsko-Zgorzeleckie Lowering), Silesian-Lusatian Lowlands

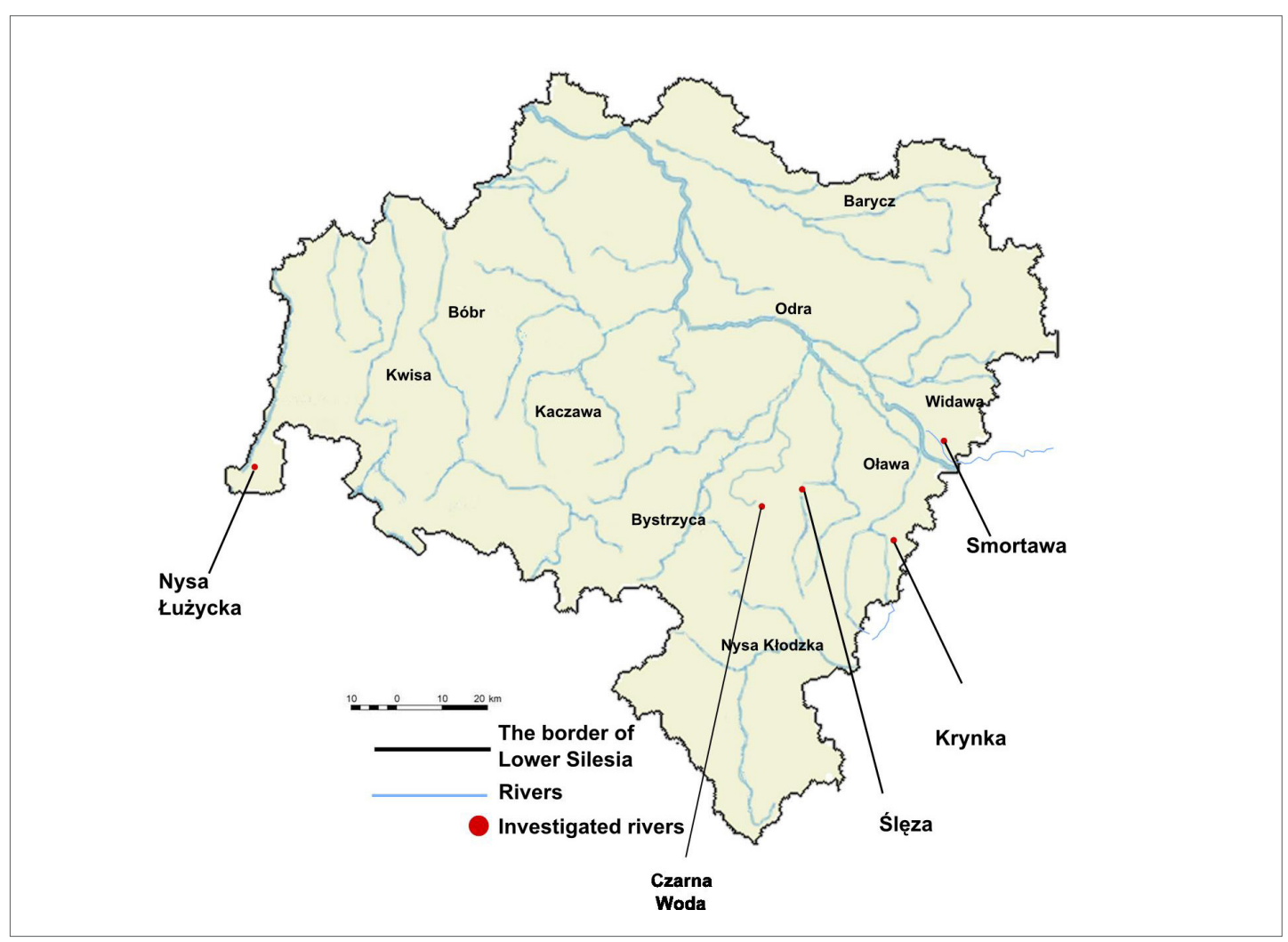

Fig 2. Location of the studied area. 
(mezoregion Lower Silesian Wilderness) and the end of the transect is located in makroregion Upper Lusatia (mezoregion Muskau Arch). The end of studied section is in Łęknica and belongs to another voivodeship - Lubusz Province.

Nysa Lużycka is a river located on the PolishGerman border. It is a left-hand tributary of the Odra river. The total length of the river is $246.09 \mathrm{~km}$ (of which $196.5 \mathrm{~km}$ constitute the Polish-German border and more than half of it is on the area of Lower Silesia) The catchment area occupy the territory of A $=4395$ $\mathrm{km} 2$ and $58 \%$ of it is in Poland. The sources of the river are in the south-western slopes of the Izerskie Mountains at an altitude of 780 $\mathrm{m}$ above the sea level. The mouth of the river is in $524+400 \mathrm{~km}$ of Odra river at an altitude of $32 \mathrm{~m}$ above the sea level (Adynkiewicz \& Lejcuś 2010). It is a typical mountain river with changeable discharges with maximum in winter and spring months. Minimum flow is reported to be in June (Staśko 2005). Nowadays the land use of the catchment is a mixture of natural areas, agricultural land, forests and areas of human activity - urban and rural building development, communication and energy infrastructure and coal outcrops. The river is always monitored (Adynkiewicz \& Lejcuś 2010).

\section{Material and methods}

Preparations for field research included literature review concerning on studied problem. There were also studies of the Polish Law in a search of riparian buffers definitions and guidelines for placing and designing them. After the verification of the law regulations, the urban plans were viewed. Local spatial developments plans according to the study area were analyzed to see if there are any implications relative to the riparian buffer zones. There were also carried out the map analysis. 1:25 000 map sheets was purchased from the Wrocław Marshal Office. The sites studies were conducted in 2012. After map analysis, rivers to the further studies have been chosen. The field research included botanical analysis, photografical documentation and phytosociological classification of the vegetation by the Braun-Blanquet method according to floristic composition. During investigations, the inventory of the rivers and assessment of the buffers zones were made. To find out which management strategy is approved by owners of the land adjacent to streams there will be taken surveys and interviews.

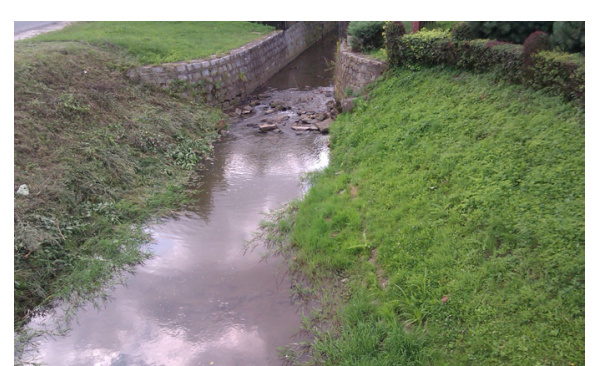

Fig 3. Limited riparian vegetation Czarna Woda (km 35+800).

\section{Czarna Woda}

The section of the Czarna Woda river covered with woody vegetation (mixed forests) consists the species like: Fagus sylvatica, Picea abies, Larix decidua, Betula pendula, Acer pseudoplatanus. The mixed forests belong to the Ślęża Landscape Park. Near sources of the river commonly can be found species like Padus avium (shrubs), Vicia cracca and an archaeophyte Cichorium intybus (flowers). Impatiens parviflora and Urtica diocica are the most frequent species within whole river banks. There are also populations of Angelica archangelica, Artemisia vulgaris and Artemisia absinthium. Riparian vegetation on this transect can be assessed as good/optimum. Unfortunately when river flows within urban area there is no riparian vegetation (eg. near Zebrzydów, km 35+8oo) and when river passes rural area the riparian vegetation is highly limited to the strips of meadows. The transect to $\mathrm{km} 20+600$ is strictly reduced in floral species. From km 19+6oo riparian vegetation is fair - reduced to small strips of meadows. There are species like Phleum pretense, Artemisia vulgaris, Artemisia absinthium. Anemone ranunculoide, Tanacetum vulgare, Euphrasia rostkoviana, Helictotrichon pubescens, Poa pratensis, Achillea millefolium, Potentilla erecta. The situation changes near Sobótka region. After passing Żerzuszyce besides meadows, riparian vegetation starts to include also woody species (Quercus robur, Quercus petraea, Carpinus betulus and Tilia cordata). From $\mathrm{km} 10+700$ to mouth of river the vegetation is good. 


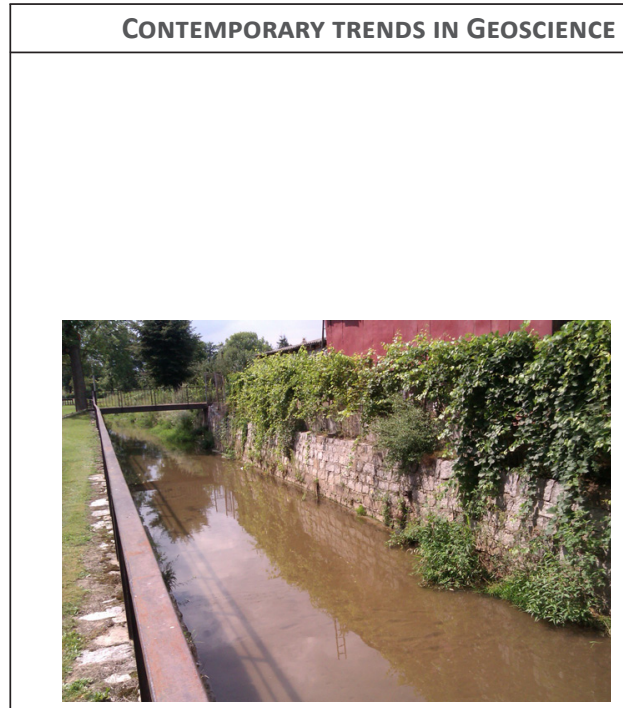

Fig 4. Czarna Woda within the town area (km 26+850). Riparian vegetation limited.

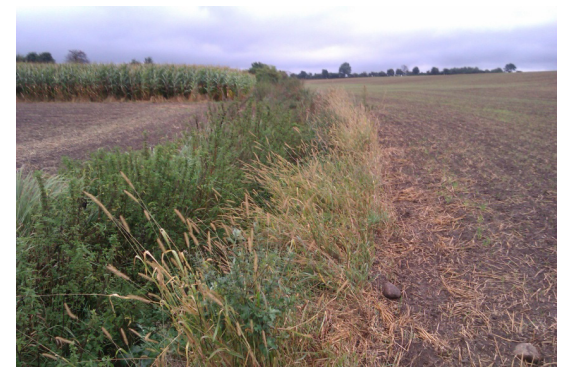

Fig 7. Bad riparian vegetation on the edge river/cropland -Smortawa (Km $38+000)$.

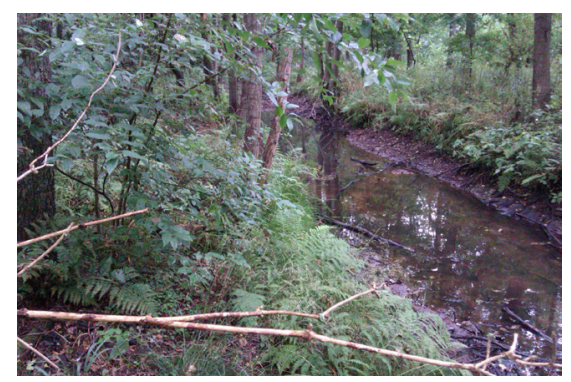

Fig 8. Good riparian vegetation - Smortawa (km 26+950).

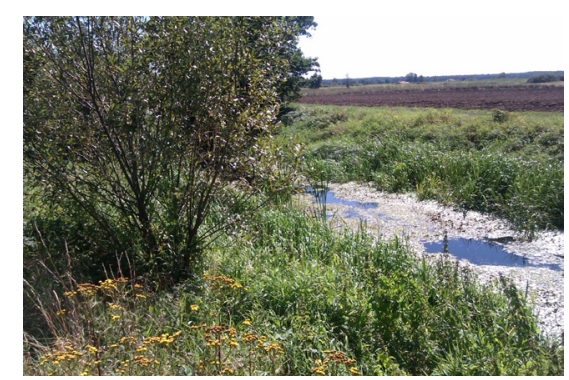

Fig 10. Riparian vegetation forming strips Smortawa (km 6+900).

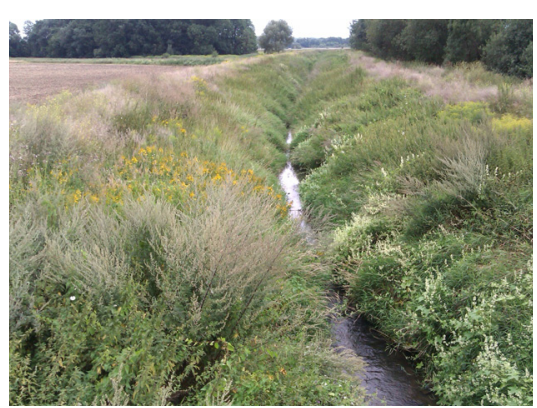

Fig 5. Czarna Woda (km 19+600) riparian vegetation forming Grass filter strip.

\section{Smortawa}

The large area of the territory within Smortawa flows is covered by forests. There have been created nature reserves like Leśna Woda Reserve. It has been created to protect the natural mixed forest of old trees, with a large proportion of European larch. Those transects of the river that draining agricultural lands were restrained to the few meters wide strips of grasses. The sources of the river near Świerczów crosses the cropland. Riparian vegetation in this place is very poor. There are single species of Padus avium, populations of Artemisia vulgaris, Phleum pretense, Arctium lappa, Hypericum perforatum, Tanacetum vulgare, Senecio jacobaea. From $\mathrm{km} 28+100$ the vegetation is more dense. The woody area starts with species forming mixed forests. The upper elevation level is represented by Fagus sylvatica, Pinus

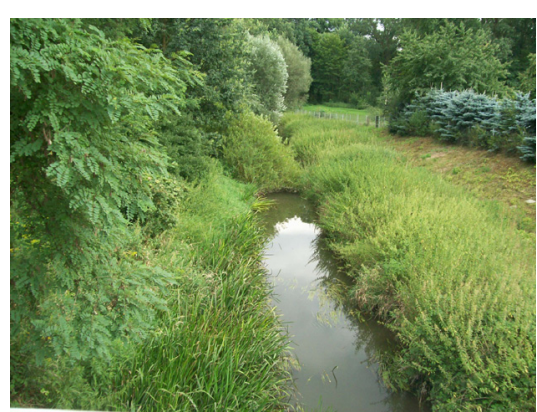

Fig 6. Good riparian vegetation - Czarna Woda $(\mathrm{km} \mathrm{10+700)}$.

sylvestris and Larix decidua, frequently appears Quercus robur and Quercus petraea, in lower elevation Carpinus betulus can be found. In many places there are also populations of Tilia cordata and Alnus glutinosa. In some places Pinus strobus occurs. In the undergrowth populations of Hedera helix massively appear and plant from genus Rubus and species like Humulus lupulus and Frangula alnus. We can also see a fern species like Polypodium vulgare. This woody transect lasts until km 21+89o near Borucice where one bank of the river is limited by the cropland. From km $21+890$ to $\mathrm{km} \mathrm{14+700} \mathrm{forests}$ vegetation continue and in $\mathrm{km} \mathrm{13+300} \mathrm{ap-}$ pears Leśna Woda. This section is also optimal for riparian vegetation. Although near Janików vegetation is again highly reduced.

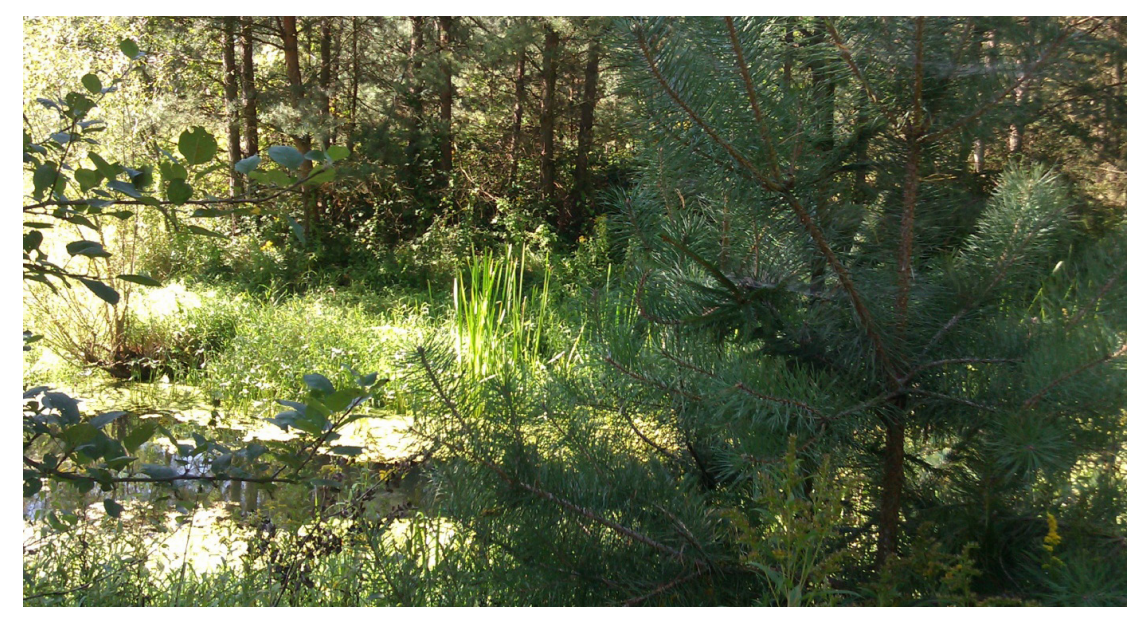

Fig 9. Optimum riparian vegetation - Smortawa (km 13+300). 


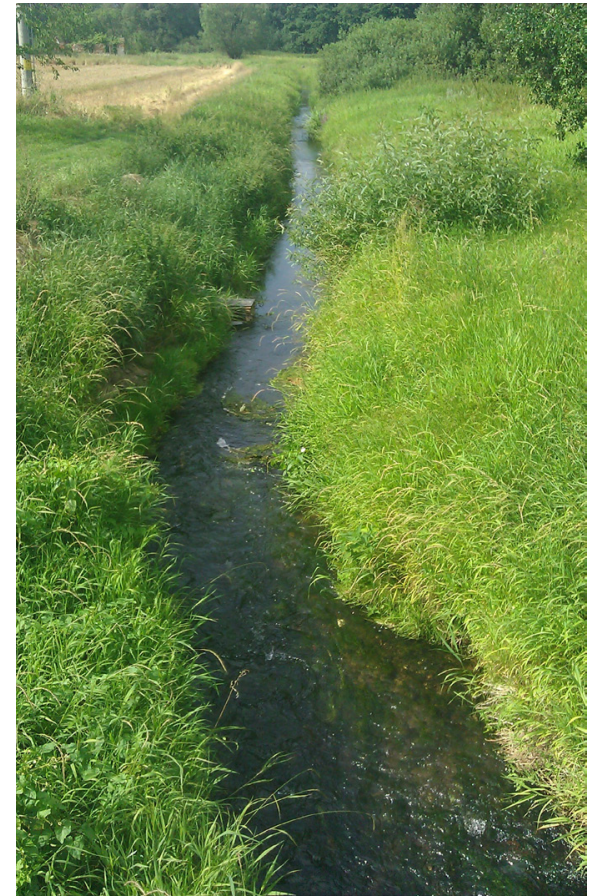

Fig 11. Riparian vegetation forming strips Krynka (km 30+850).

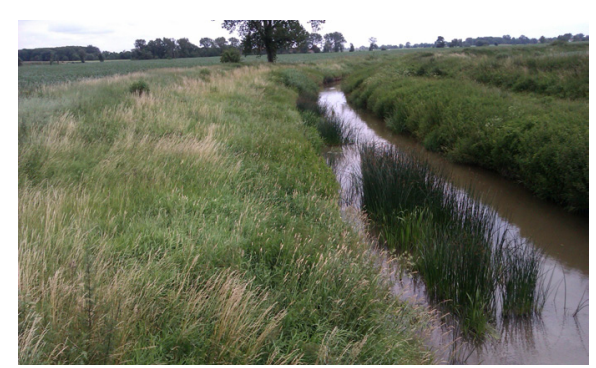

Fig. 14. Riparian vegetation forming buffer strip. Single individuals of woody species. Ślęza river (Km 29+300).

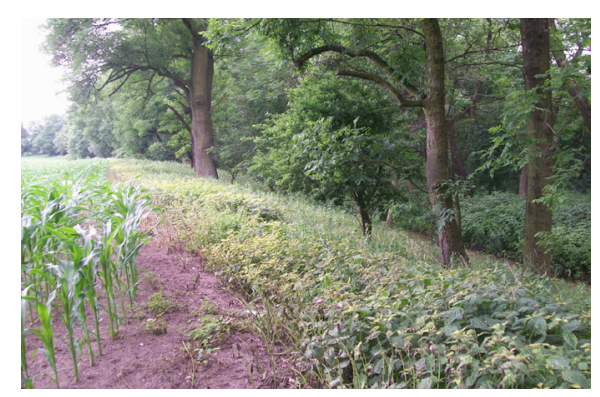

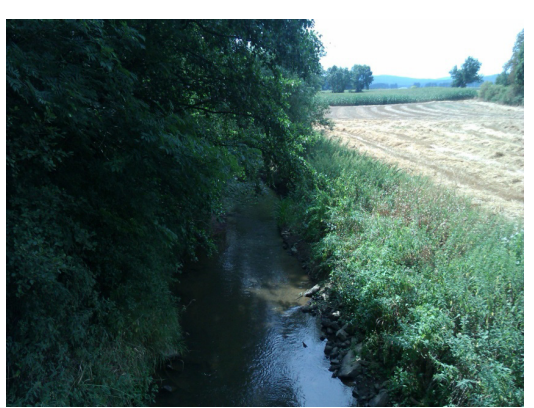

Fig 12. Riparian vegetation different types on different banks-Krynka (km 6+400).

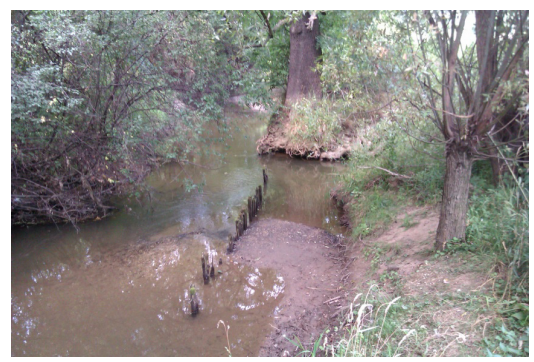

Fig 13. Riparian forests- Krynka (km 4+250).

\section{Ślęża}

The section of this river that flows from Wroclaw city to Ślęza village ( $\mathrm{km} \mathrm{14+700} \mathrm{to}$ $\mathrm{km} \mathrm{17+500)}$ is bereft of the woody vegetation. The vegetation is bad- only patches of single species and small grassy strips. There are only single species of trees in patches but mostly riparian zone is constituted of grasses and sometimes shrubs. The situation changes near Ślęza village where riparian forests occurs. This is typical mixed forest with representative species like Quercus robur and Quercus petraea. In the undergrowth there are populations of dragged Impatiens parviflora and commonly occurrs Urtica dioc-

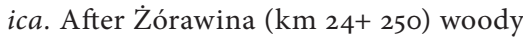

Fig 15. The example of edge cropland/riparian forest. ślęża river (Ślęża village km 19+300).

\section{Krynka}

The source of river is in agricultural area. The vegetation of riverbanks is limited there to patches and strips of grasses and wildflowers like Campanula trachelium, Campanula rotundifolia, Convolvulus arvensis, Potentilla erecta, Myosotis arvensi. There are also plants like Trifolium pretense, Taraxacum officinale, Vicia cracca, Senecio jacobae, Tanacetum vulgare. Herbaceous strips are formed with plants like Poa pratensis, Artemisia vulgaris. Agropyron repens, Urtica dioica .This kind of strips lasts almost the whole part of the river that is located in Opole Province. In lower Silesia in $\mathrm{km} 18+850$ individual and groups of trees appear. In 2006 there was made a documentation to create The Ecological Park of Krynka Valley from km 16+30o to the mouth of the river in Krzepice. The most precious in this area are riparian forests and broadleaved forests that constitute the Natura 2000 and can be included to optimum riparian zones. They are consisted of Quercus robur and Quercus petraea, Ulmus minor and Fraxinus excelsior. The forest management was not intensive in this area so the old trees are preserved in good shape.

vegetation changes into strips consisted of meadows. The floral species include mostly different types of grasses (Helictotrichon pubescens, Dactylis glomerata, Festuca pratensis), weeds and sometimes flowers like Anemone ranunculoide, Centaurea cyanus, Potentilla erecta, an archaeophyte Papaver rhoeas, Matricaria chamomilla. There are commonly found species like Taraxacum officinale, Trifolium arvense, Lathyrus tuberosus. Weeds are represented by Calamagrostis epigeios, Elymus repens, Artemisia camprestris. The other common plant frequently encountered is Achillea millefolium. Until the

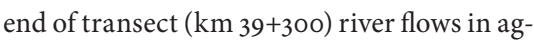
ricultural area so vegetation closest to the river include macrophytes like Phragmites australis, Schoenoplectus lacustris and grass filter strips consists of meadows. 


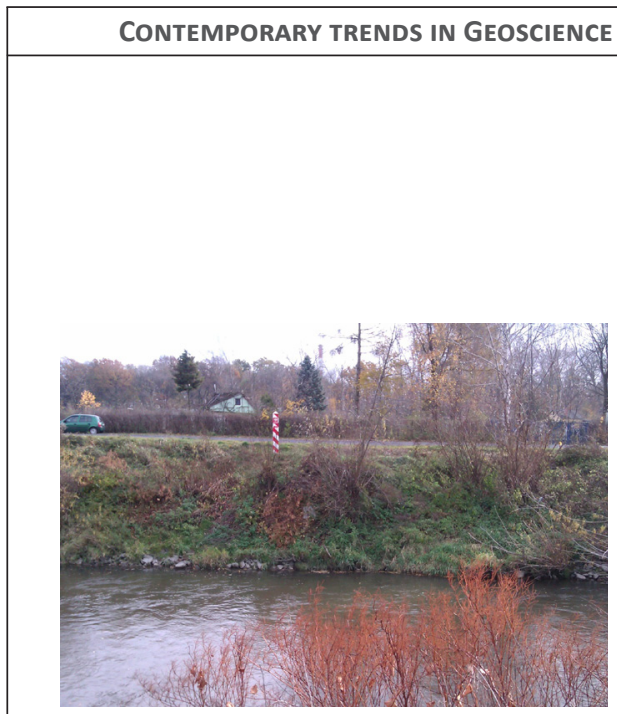

Fig 16. Limited vegetation near urban areaNysa Łużycka (km 149+300).

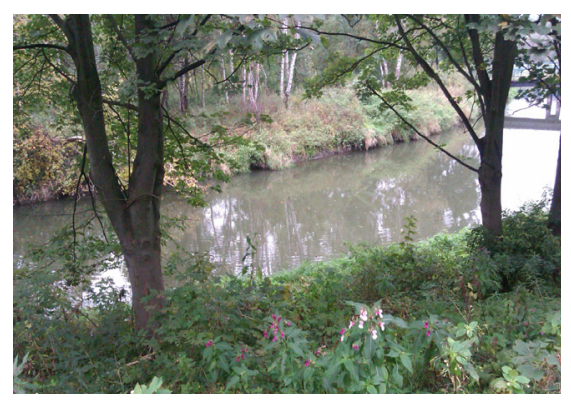

Fig 17. Good riparian vegetatikon Nysa łużycka (km 138+600).

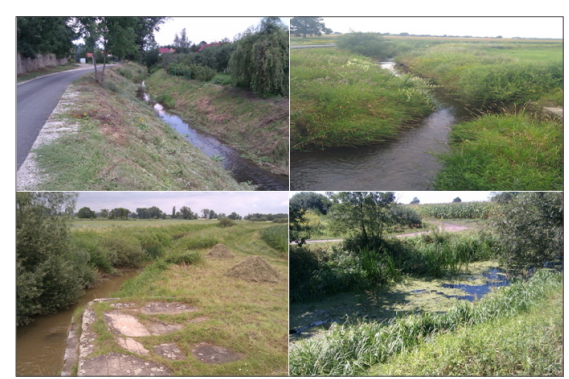

Fig 18. Variety of river edges in rural areas. From left handcorner: 1) Czarna Woda (Km $35+900)$, Krynka (Km 18+850) , ślęza (Km $25+750)$, Smortawa ( Km 6 +960).

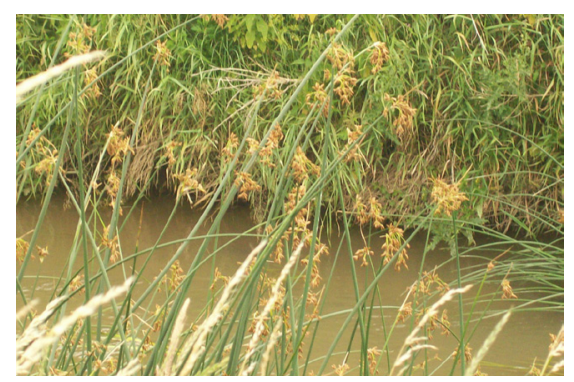

Fig 19. Schoenoplectus lacustris at the side

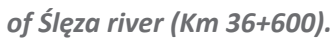

VOL. 2

Riparian buffer zones on selected rivers in Lower Silesia - an important conservation

practice and the management strategy in urban planning
Nysa Łużycka

Except urban area of Zgorzelec and adjacent

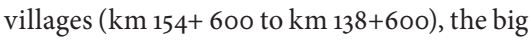
part of studied transect is located within area of Lower Silesian Wilderness where typical habitat is fresh coniferous forest with characteristic species - the most frequently appeared Pinus sylvestris but the contribution of Picea Abies is steadily growing. In many places occurs reintroducted Abies alba. Deciduous species are represented generally by Quercus robur and Quercus petraea but also, Betula

pendula, Fagus sylvatica, Alnus glutinosa and Populus tremul. The lower level is occupied by Juniperus communis, Euonymus europaeus and Sorbus aucuparia. In undergrowth we can see Osmunda regalis and Vaccinium myr tillus, Vaccinium vitis-idaea, Deschampsia flexuosa (bunchgrass), Calamagrostis arundinacea (grass). Invasive species are represented by Prunus serotina. This kind of vegetation can be included to optimum ones.

\begin{tabular}{|l|l|l|l|}
\hline Trees & Shrubs & Grasses & Wildflowers \\
\hline Quercus robur & Padus avium & Festuca ovina & Vicia cracca \\
\hline Quercus petraea & Frangula alnus & Festuca rubra & Campanula trachelium \\
\hline Salix alba & Rubus parviflorus & Festuca pratensis & Campanula patula \\
\hline Alnus glutinosa & Salix caprea & Poa pratensis & Campanula rotundifolia \\
\hline Populus alba & Crataegus laevigata & Poa trivialis & Convolvulus arvensis \\
\hline Populus nigra & Sambucus nigra & Anthoxanthum odoratum & Cerastium holosteoides \\
\hline Sorbus aucuparia & Viburnum opulus & Arrhenatherum elatius & Myosotis scorpioides \\
\hline Fagus sylvatica & Juniperus communis & Dactylis glomerata & Gladiolus imbricatus \\
\hline Larix decidua & Euonymus europaeus & Helictotrichon pubescens & Galium odoratum \\
\hline Pinus sylvestris & & Holcus lanatus & Anemone ranunculoides \\
\hline Carpinus betulus & & Agrostis capillaris & Anemone nemorosa \\
\hline Tilia cordata & & Agrostis gigantea & Taraxacum officinale \\
\hline Fraxinus excelsior & & Phleum pratense & Polygala vulgaris \\
\hline & & & \\
\hline
\end{tabular}

Table 1. Commonly used native species in Lower Silesia
In addition, in every studied riparian vegetation there are also many antropofits for example : trees like Quercus rubra, Aesculus hippocastanum (trees,) Reynoutria japonica (shrubs), Rubus (shrubs), Cornus alba - domesticated antropomorphit. Dragged species like Artemisia absinthium and Artemisia vulgaris are quite popular on riparian areas where vegetation cover includes only patches of meadows. Invasive species are represented by Solidago gigantean, Solidago Canadensis, Helianthus tuberosus, Heracleum sosnowskyi and Bidens frondosa. In every riverside there were many populations of Urtica diocica which indicates Nitrogen in soils.

\begin{tabular}{|l|l|l|}
\hline MACROPHYTES & POLISH NAME & RIVER \\
\hline Glyceria maxima & Manna mielec & Czarna Woda, Ślęza \\
\hline Elodea canadensis & Moczarka kanadyjska & Czarna Woda \\
\hline Sagittaria sagittifolia & Strzałka wodna & Czarna Woda, Smortawa \\
\hline Phalaris arundinacea & Mozga trzcinowata & Czarna Woda, Smortawa \\
\hline Schoenoplectus lacustris & Oczeret jeziorny & Slęza, Czarna Woda \\
\hline Lemna minor & Rzęsa drobna & Czarna Woda, Ślęza, Nysa Łużycka \\
\hline Callitriche verna & Rzęśl wiosenna & Czarna Woda \\
\hline Stuckenia filiformis & Rdestnica nitkowata & Czarna Woda \\
\hline Nuphar lutea & Grążel żółty & Ślęza, Smortawa \\
\hline Typha angustifolia & Pałka wąskolistna & Smortawa \\
\hline Hydrocharis morsus-ranae & Żabiściek pływający & Smortawa \\
\hline Sparganium emersum & Jeżogłówka pojedyncza & Smortawa \\
\hline Phragmites australis & Trzcina pospolita & Ślęza, Czarna Woda, Nysa Łużycka, Krynka \\
\hline Schoenoplectus lacustris & Oczeret Jeziorny & Ślęza, Nysa Łużycka \\
\hline Utricularia vulgaris & Pływacz Zwyczajny & Nysa Łużycka \\
\hline
\end{tabular}

Table 2. Macrophytes species recognized at investigated riversides. 
Discussion The importance of the riparian vegetation is well known. The sustainability of farming systems and use of the best management practices in agriculture should be major goal to achieve in environment management and urban planning (Basset-Mens et al. 2006). Riparian buffer strips in good condition are widely noted because they are able to perform a variety of functions. that is the reason why they should be maintain with special care. The rise of the vegetation at the river banks has the potential to improve whole ecosystem health (Kenwick et al. 2009).

The ability of a riparian zone to provide a range of multiple environmental functions depends on the following factors: width, length, degree of fragmentation, and type, density, and structure of vegetation present. Objectives that also play role include land ownership, existing or potential riparian vegetation, soils, slope, or past land-uses both within the riparian zone and in uplands throughout the watershed (Fisher et al. 2000). It would be useful to implement a general guidelines for buffer sizes. Buffer size requirements may belong to one of 2 categories: fixed-width and variable-width. Buffer less than 5-10 m provide only little protection of aquatic environment under most conditions. Based on literature, minimum width of the buffers that is necessary to protect wetlands and streams should be 15-30 m (Castelle et al. 1994). Although, much greater widths (i.e.,
$>100 \mathrm{~m})$ are required to assure values related to wildlife habitat and use as migration corridors. If there is only a possibility of a narrow buffer strip, it should at least be wide enough to sustain a forest or shrub community, that will properly stabilize the streambank from erosion (Fisher et al. 2000).

Site specific conditions should be taken into consideration because they can indicate larger or somewhat smaller buffer widths (Castelle et al. 1994).

Too narrow buffers provide inadequate protection, too wide - will reduce the area of productive crop (Broadmeadow \& Nisbet 2004). Unfortunately, it is impossible to estimate definitive buffer width that will protect water resources from every existing threat (Fisher et al. 2000). The spatial placement of buffer strips within a catchment results in many positive effects on water quality. Although buffer strips are important along all rivers and streams, those in headwater streams often have much greater influences on overall water quality within a watershed than those buffers occurring in downstream reaches (Fisher et al. 200o).

In the United States a large amount of state and national mitigation programs have been established to support practices leading to water quality improvement (Lee et al. 2004). The model of riparian buffer zone was shown in Chesapeake Bay Riparian Handbook (1997). Authors distinguished different type

\begin{tabular}{|l|l|l|l|}
\hline Optimum & Good & Fair & Bad \\
\hline$>75 \%$ of & Riparian & Riparian veg- & Riparian vegeta- \\
stream & vegetation & etation is & tion is absent or \\
length has & appears in & reduced, & very scarce, \\
woody & patches, & forming small & represented by \\
riparian & covering 50- & patches cov- & isolated \\
vegetation, & $75 \%$ of & ering 25-50 & or small groups \\
forming a & the stream & of stream & (1-3 \\
continuous & length, or & length & individuals) of \\
and dense & covers $>75 \%$ & & trees or \\
vegetated & forming & & ing less \\
corridor & an open, low & & than $25 \%$ of \\
& density & & stream \\
& vegetated & & length \\
\hline
\end{tabular}

Table 3. Continuity of riparian vegeta-

tion (woody species)

(González del Tánago 2006). 


\begin{tabular}{|l|l|l|}
\hline CONTEMPORARY TRENDS IN GEOSCIENCE & VOL . 2 & MARYNA ADAMSKA \\
\hline & $\begin{array}{l}\text { Riparian buffer zones on selected rivers in Lower Silesia - an important conservation } \\
\text { practice and the management strategy in urban planning }\end{array}$ \\
\cline { 2 - 3 }
\end{tabular}

of riparian vegetation according to the kind of landscape. As the example, there were Streamside Management Zones in forested landscapes (a zones where timber management Practices are modified), Agricultural Riparian Forest Buffers in agricultural landscapes (area of trees and other vegetation separating cropland or pasture from a stream) and Suburban Riparian Forest Buffer (corridors of forest bordered by parks, ballfields, roadways, lawns, and residential/commercial structures) and Urban Riparian Forest Buffer (corridors or strips of forest, which are protected, managed, and/or enhanced for aesthetic, habitat, recreational, climatic, or water quality benefits within a highly impervious setting). That many types of riparian vegetation was recognized only in United States, but guidelines created in Australia and New Zealand are also specific and depends on many important objectives as a slope and land use type. The minimum buffer width is $10 \mathrm{~m}$ the maximum more than $100 \mathrm{~m}$ (every state has own jurisdiction, so the recommendations vary). In European Union there are no general guidelines of implementing riparian areas, but the law enforce to construct and maintain these zones and in some countries like Germany or Estonia, the minimum buffer widths were established. If we compare the zones on rivers in Lower Silesia to the model zones from United States we can see that the first difference is there is no maintaining on polish riparian vegetation. Sometimes landowners even expand their crop fields to the river banks. Streams within urban areas are often bereft of the floral species. Healthy riparian vegetation can be provided even in urban area and this is a goal that we try to achieve.

Environmental planners should realize the importance of maintaining existing or newly constructed riparian buffers when land is developed for urban purpose The design and placement of strips are important in the planning of riparian buffer zones, since they can have a large influence on the control efficiency of water quality and water quantity The factors that influence the performance of riparian buffer strips include width, slope, soil properties, vegetation and flow rate, etc. Riparian buffer strips have been an important conservation practices for watershed management for a long time. The planning of riparian buffer strips should consider many aspects rather than only the control effectiveness of runoff and pollutant loadings (Chang et al. 2010). Only good management of the uplands and healthy riparian zones will completely protect the quality and functioning of the receiving waters (Correl 2005).

\section{Conclusions}

Unfortunately, many of riparian buffers zones in Lower Silesia are limited and cannot function properly. Some transects of selected rivers that are located within rural area and drainaging agriculture lands can suffer because of the livestock grazing and crop production. The sections in the vicinity of the cities may be exposed to the anthropopressure. Only sections within places included conservation practices like Natura 2000 could be assessed as a optimal and good zones. Other parts have insufficient vegetation and could be specified as a fair. In some places (eg. Zebrzydów, Szczepanów - river Czarna Woda) there were no riparian zones and the floral species were represented only by small groups of individuals. In Polish law there is no clear definition of riparian buffer zone, which is unacceptable, because we declared to accept the law from European Union.
There are only mentions in regulations concerning on financial support for landowners that will allocate part of their land for riparian zones. But there are no directions how they can design and create such a zone. The extent and width of riparian buffers haven't been defined. Because these vegetation zones play many important ecological roles, in every place adjacent to a water course, where it is possible, we need to endeavor to maintain and improve existing riparian buffers. In places where riparian vegetation is limited, there should be create plantings made of native species especially from grasses. Even small grass filter strip is better than no barrier that protects river from agriculture contaminants. If we start to use best management practice we could save our water resources more effectively. 
Adynkiewicz-Piragas, M., Krzemińska, A., Tarnowski, K., Wróblewski, T. (2006) Charakterystyka i zróżnicowanie parametrów hydromorfologicznych w rzece nizinnej na przykładzie Smortawy, Infrastruktura i ekologia terenów wiejskich 4,3,17-24

Adynkiewicz-Piragas, M., Lejcuś, I., (2010) Propozycja wykorzystania oceny hydromorfologicznej w badaniach krajobrazowych regionu pogranicza Nysy Łużyckiej, Problemy Ekologii Krajobrazu, XXVI, 145-160

Agouridis, C.T., Wightman, S.J., Barton, C.D., Gumbert, A.A. [online].(2010) Planting a Riparian Buffer, Cooperative Extension Service, University of Kentucky College of Agriculture, Lexington, KY, 40546 Available on the Internet: http://www. ca.uky.edu/agc/pubs/id/id185/id185.pdf

Basset-Mens, C., Anibar, L., Durand, P., van der Werf H.M.G. (2006) Spatialised fate factors for nitrate in catchments: Modelling approach and implication for LCA results, Science of the Total Environment $367,367-382$

Blackwell, M.S.A., Hogan, D.V., Maltby, E. (1999) The use of Conventionally and alternatively located buffer zones for the removal of nitrate from diffuse agricultural run-off, Water Science and Technology 39,12,157-164

Broadmeadow, S., Nisbet, T.R., (2004) The effects of riparian forest management on the freshwater environment: a literature review of best management practice, Hydrology and Earth System Sciences, 8, 3, 286-305

Burt, T.P., Pinay, G., Matheson, F.E., Haycock, N.E., Butturini, A., Clement, J.C., Danielescu, S., Dowrick, D.J., Hefting, M.M., Hillbricht-Ilkowska, A., Maitre, V. (2002) Water table fluctuations in the riparian zone: comparative results from a pan-European experiment, Journal of Hydrology, 265, 129-148

Castelle, A.J., Johnson, A.W., Connolly, C. (1994) Wetland and stream buffer size requirements - a review, Journal of Environmental Quality, 23, 878-892

Chang, C.-L., Hsu, T.-H., Wang, Y.-J., Lin, J.-Y., Yu S. L. (2010) Planning for Implementation of Riparian Buffers in the Feitsui Reservoir Watershed, Water
Resources Management 24, 2339-2352

Correll, D.L. (2005) Principles of planning and establishment of buffer zones, Ecological Engineering 24, 433-439

Fielding, K.S., Terry, D.J., Masser, B.M., Bordia, P., Hogg, M.A. (2005) Explaining landholders' decisions about riparian zone management: The role of behaviour al, normative, and control beliefs, Journal of Environmental Management, 77, 12-21 Fischer, R.A., Fischenich, J.C. [online]. (2000) Design recommendations for riparian corridors and vegetated buffer strips, EMRRP Technical Notes Collection (ERDC TNEMRRP-SR-24), U.S. Army Engineer Research and Development Center, Vicksburg, MS, www.wes.army.mil/el/emrrp Fischer, R.A., Martin, C.O., Fischenich, J.C. (2000) Improving riparian buffer strips and corridors for water quality and wildlife, In: International Conference on Riparian Ecology and Management in Multi-land Use Watersheds, American Water Resources Association, August 2000, 1-7

González del Tánago, M., García de Jalón, D., Lara F., Garilleti, R. (2006) Índice RQI para la valoración de las riberas fluviales en el contexto de la Directiva Marco del Agua. Ingeniería Civil, 143: 97-108

Kasprzak, M, (2010) Wezbrania i powodzie na rzekach Dolnego Śląska, In: Wyjątkowe zdarzenia przyrodnicze na Dolnym Śląsku i ich skutki, P. Migoń (eds), Rozprawy Naukowe Instytutu Geografii i Rozwoju Regionalnego 14, Wrocław (In Polish)

Kenwick, R.A, Shammin, Md.R., Sullivan, W.C. 2009 Preferences for riparian buffers, Landscape and Urban Planning, 91, 88-96 Kondracki, J. (2002) Geografia regionalna Polski, Polskie Wydawnictwo Naukowe, Warszawa (In Polish)

Lee P., Smyth C., Boutin S. 2004. Quantitative review of riparian buffer width guidelines from Canada and the United States. Journal of Environmental Management 70,165-180 Malczewska, B., Gromada, O., Jawecki, B. (2011) Gospodarka zasobami wodnymi na przykładzie gminy i powiatu Strzelin, Infrastruktura i ekologia terenów wiejskich 7, 133-143

Palone R.S., Todd A.H. (eds) (1997). Chesapeake Bay riparian Handbook: a guide for Establishing and Maintaining Riparian 
Forest Buffers. USDA Forest Service NATP-02-97, Radnor, PA.

Parzóch, K., Solarska, A. (2008) Antropogeniczna przebudowa den dolinnych Przedgórza Sudeckiego na przykładzie Oławy i Krynki, Landform Analysis, 9, 314-318

RozporząDZENIE RAdy (WE) NR 1257/1999 z dnia 17 maja 1999 r. w sprawie wsparcia rozwoju obszarów wiejskich ze środków Europejskiego Funduszu Orientacji i Gwarancji Rolnej (EFogR) oraz zmieniające i uchylające niektóre rozporządzenia

Rozporządzenie Rady (WE) NR 73/2009 z dnia 19 stycznia 2009 r. ustanawiające wspólne zasady dla systemów wsparcia bezpośredniego dla rolników w ramach wspólnej polityki rolnej i ustanawiające określone systemy wsparcia dla rolników, zmieniające rozporządzenia (WE) nr 1290/2005, (WE) nr 247/2006, (WE) nr $378 / 2007$ oraz uchylające rozporządzenie (WE) nr 1782/2003

Rozporządzenie KomisJi Europejskiej 445/2002 z dnia 26 lutego $2002 \mathrm{r}$. ustanawiające szczegółowe zasady stosowania rozporządzenia Rady (WE) nr 1257/1999 w sprawie wsparcia rozwoju obszarów wiejskich ze środków Europejskiego Funduszu Orientacji i Gwarancji Rolnej (EFOGR)

Schultz, R.C., Isenhart, T.M., Simpkins, W.W., Colletti, J.P. (2004) Riparian forest buffers in agroecosystems - lessons learned from the Bear Creek Watershed, central Iowa, USA, Agroforestry Systems 61,35-50 